\title{
DAYA TARIK IKLAN POLITIK PADA PEMILU LEGISLATIF
}

\author{
Irtanto \\ Badan Litbang Provinsi Jawa Timur \\ Jl. Gayung Kebonsari No 56 Surabaya Fax 0318290719 \\ Jawa-Timur. Email irtanto@ @rocketmail.com No HP. 081615256958 \\ Naskah dikirim tanggal 1 Desember 2011, disetujui tanggal 24 April 2012
}

\section{ATTRACTIVENESS OF POLITICAL ADVERTISEMENT IN LEGISLATIVE ELECTIONS}

\begin{abstract}
This study is an exploratory with quantitative descriptive approach that aimed to know the use of media introduction of legislative candidates in the election 2009, identifying political advertising appeal of political parties and the priority programs that attract voters and voter perception of the role of communications media in the 2009 legislative elections. The results showed that media socialization during the 2009 election was less a role as well. Political advertising political parties that they offer relatively attractive. Communication medium are television, internet, newspapers effectively to influence voters and taken into consideration in selecting candidates. Similarly, the communication media through religious organizations and people associations are seen as more effective to influence voters. While those with middle-lower education tend to be political orientation on the choice of ideology, while those with high education are more likely in the political orientation of problem solving policy.
\end{abstract}

Keywords: legislative elections, the mass media, candidate and politic advertise

\begin{abstract}
Abstrak
Penelitian ini bersifat eksploratif dengan pendekatan deskriptif kuantitatif antara lain bertujuan untuk mengetahui penggunaan media pengenalan kandidat pada pemilu legislatif 2009, mengidentifikasi daya tarik iklan politik parpol dan prioritas program yang menarik pemilih serta mengetahui persepsi pemilih terhadap peran media komunikasi pada pemilu legislatif 2009. Hasil penelitian menunjukkan bahwa media sosialisasi pada saat pemilu 2009 masih kurang berperan dengan baik. Iklan politik parpol yang mereka tawarkan relatif menarik. Media komunikasi yang digunakan berupa televisi, internet, surat kabar efektif untuk memengaruhi pemilih dan dijadikan pertimbangan dalam memilih kandidat. Demikian juga media komunikasi lewat organisasi keagamaan dan perkumpulan warga dipandang lebih efektif untuk memengaruhi pemilih. Sedangkan mereka yang berpendidikan menengah-bawah cenderung orientasi politik pada pilihan ideologi, sedangkan mereka yang berpendidikan tinggi lebih cenderung orientasi politiknya pada "problem solving policy".
\end{abstract}

Kata Kunci: pemilu legislatif, media massa, iklan politik dan kandidat 


\section{PENDAHULUAN}

Pemilihan umum legislatif 2009 secara langsung yang memilih kandidat merupakan format baru dalam sistem politik nasional. Mengapa demikian? Sebab sejak orde lama hingga pemilihan legislatif 2004 selalu memilih partai politik. Bukan memilih kandidat/orang secara langsung. Jawa Timur terutama perkotaan merupakan daerah padat penduduk. Oleh karena itu dalam pemilihan umum legislatif 2009 daerah perkotaan menjadi tempat kampanye yang cukup menarik untuk diperebutkan oleh berbagai partai politik peserta pemilu. Apalagi daerah perkotaan diduga pemilihnya kebanyakan cenderung pemilih rasional, tidak salah jika iklan politik merupakan strategi marketing politik bertebaran di mana-mana. Berbagai iklan politik tersebut bertebaran di berbagai media komunikasi seperti internet, surat kabar, televisi, radio, selebaran, atau baliho, dan sebagainya dengan tujuan untuk memengaruhi perilaku politik pemilih.

Iklim politik yang penuh dengan persaingan terbuka dan transparan, kontestan membutuhkan suatu metode yang dapat memfasilitasi mereka dalam memasarkan inisiatif politik, gagasan politik, isu politik, ideologi partai, karakteristik pemimpin partai, dan program kerja partai kepada masyarakat. Oleh karena itu perlu suatu strategi untuk dapat memenangkan persaingan politik. Untuk memenangkan persaingan politik antara lain dengan jalan marketing politik lewat media massa. Media massa memiliki kemampuan untuk memengaruhi opini publik dan perilaku masyarakat (Klapper, 1960). Media dianggap memiliki peran yang sangat penting dalam mentransmisi dan menstimulasi permasalahan politik. Cakupan yang luas dalam masyarakat membuat media massa dianggap sebagai salah satu cara yang efektif dalam mengomunikasikan program kerja, pesan politik, pembentukan image partai atau seseorang. Media yang memiliki cakupan luas ini dapat berupa koran, majalah, televisi, radio, dan internet. Masing-masing media ini memiliki jaringan distribusi luas dan dapat mengantarkan berita serta informasi yang mudah dijangkau dan diakses oleh publik.

Media massalah yang pada akhirnya dijadikan ajang rebutan partai politik untuk menampilkan kandidatnya. Demikian sebaliknya media massa tidak jemu-jemu dan tidak henti-hentinya menampilkan berbagai kandidat politik, dengan berbagai variasi dan polesan performennya. Pada akhirnya media massa dijadikan rebutan para kandidat politk baik pusat maupun daerah. Perkembangan media nasional maupun lokal di Indonesia akhir-akhir ini sangat cepat, terutama sejak swasta diberi kesempatan untuk mengelola televisi. Akhir tahun 80-an tercatat 11 stasiun TV nasional (TVRI, TPI, RCTI, SCTV, ANTV, METRO TV, INDOSIAR, TRANS TV, BLOBAL TV, TV 7, dan TV One) ditambah dengan stasiun TV lokal di setiap daerah. Selain itu ada TV Kabel yang dapat merelay program TV Global. Belum lagi media cetak dan radio yang tidak terhitung jumlahnya.

Hiruk pikuk pemilu menggema di mana-mana, iklan politik bertebaran tidak terhitung kuantitas dan kualitasnya. Tidak ketinggalan partai politik yang berjumlah 34 yang ikut pemilu memanfaatkan berbagai media komunikasi, baik itu media massa seperti surat kabar, selebaran, baliho, dan media elektronik seperti internet, televisi, radio serta media komunikasi personal. Tidak mengherankan jika rakyat disuguhi dengan janji-janji politik yang menggiurkan pemilih, baik partai politik maupun kandidat.

Perebutan media massa pada saat kampanye oleh kandidat maupun partai politik sangat tajam, mereka berusaha memengaruhi opini publik. Demi popularitas kandidat ataupun partai politik tidak sedikit uang yang dihabiskan demi memasang sebuah iklan politik untuk meraih sebuah kekuasaan. Demikian pula sebaliknya, tampaknya media massa tidak ketinggalan pula memanfaatkan situasi yang menguntungkan untuk kepentingan bisnis media massa. Untuk meyakinkan para pemilih kandidat, partai politik menawarkan berbagai programnya yang seolah-olah semuanya untuk kepentingan rakyat.

Permasalahan yang dikaji dalam penelitian ini adalah: 1. Sejauhmana peran 
media sosialisasi pada pemilu legislatif 2009? 2. Sejauhmana penggunaan media pengenalan kandidat pada pemilu legislatif?. 3. Seberapa besar daya tarik iklan politik parpol dan prioritas program apa saja yang menarik pemilih? 4. Sejauhmana persepsi pemilih terhadap peran media komunikasi pada pemilu legislatif 2009 ?

\section{LANDASAN KONSEP}

Kebutuhan manusia untuk berkomunikasi didorong oleh rasa ingin tahu atau membutuhkan sesuatu. Dengan demikian berkaitan dengan motivasi dan aspirasi seseorang, yaitu harapan dan cita-cita yang menyangkut kehidupan seseorang. Asumsi yang mendasari adalah bahwa untuk mendapatkan aspirasinya, maka individu membutuhkan informasi. Konsep informasi diartikan sebagai "penjelasan atau keterangan" mengenai sesuatu. Oleh karena itu manusia memerlukan informasi, baik yang bersumber dari media massa maupun media interpersonal. Pemanfaatan media dan pemuasan kebutuhan (uses and gratifications) berasumsi (Rosadi, 1999) bahwa: Pertama, pemanfaatan media diarahkan pada tujuan memuaskan kebutuhan tertentu, termasuk di dalamnya adalah informasi; Kedua, penerima menyeleksi tipe media dan isi media untuk memenuhi kebutuhan; Ketiga, terdapat sumber lain yang digunakan untuk memuaskan kebutuhan; dan keempat khalayak menyadari kebutuhannya dan dapat melaporkan kalau dirinya ditanya. Selanjutnya Mc. Quail (1996) membagi empat fungsi media yaitu 1) media meyediakan informasi tentang lingkungan, 2) media menyediakan kesempatan untuk melarikan diri dari kerutinan dan beban masalah dan sebagai wahana melepas emosi (escape/disverse), 3) media sebagai wahana rujukan personal, eksplorasi realitas dan penguatan nilai (personal identity), 4) media menyediakan peluang untuk menambah persahatan dan hubungan sosial (social integrations).

Media massa dapat memperluas cakrawala pemikiran, mampu menumbuhkan aspirasi dan merangsang masyarakat untuk bekerja lebih baik (Schram, dalam Depari dan Andrews, 1995). Ada dua cara memperoleh informasi, bersumber dari media massa dan melalui komunikasi interpersonal yaitu merupakan proses sosial orang-orang yang terlibat di dalam proses tersebut saling memengaruhi. Dalam Teori Penyatuan (Convergence Theory) cenderung mandiri dan berfungsi sebagai bantuan "pilihan otonom" untuk melindungi kebebasan masyarakat mengambil pilihan tentang media mereka dan bentuk kebudayaan lainnya untuk menangkal (Mc. Quail, 1996).

Menurut fungsinya agenda setting media massa adalah kemampuan media massa untuk menyeleksi dan menekankan beberapa topik, menyebabkan publik menerima topik tersebut sebagai topik yang penting. Cohen (1963) dalam The Press and Foreign Policy menjelaskan bahwa pers tidak mungkin banyak berhasil memengaruhi apa yang dipikirkan orang, tapi lebih berhasil untuk membentuk persepsi orang tentang apa yang dianggapnya penting.

Penilaian terhadap isu dan kandidat bukanlah sesuatu yang terjadi secara tiba-tiba, namun sering dipengaruhi oleh informasi yang diterima pemilih melalui media massa yang diikutinya. Berita dan komentarkomentar yang dimuat di media massa, khususnya berita atau komentar-komentar negatif, seringkali memengaruhi penilaian terhadap kandidat, posisi kandidat dalam suatu isu, dan preferensi kandidat dalam suatu kebijakan tertentu (Hetherington, 1996).

Faktor-faktor yang memengaruhi perilaku politik individu aktor politik yang dikembangkan oleh M. Brewster Smith (dalam Surbakti, 1992), antara lain lingkungan sosial politik tak langsung, seperti sistem politik, sistem ekonomi, sistem budaya, dan media massa. Demikian juga faktor lingkungan sosial politik tak langsung memengaruhi lingkungan sosial politik langsung berupa sosialisasi, internalisasi, dan politisasi. Faktor lingkungan sosial politik langsung berupa sosialisasi, internalisasi, dan politisasi akan memengaruhi struktur kepribadian (sikap).

Media massa mempunyai peran yang 
sangat penting di dalam proses pemilu. Media massa memiliki kemampuan untuk memberitakan informasi secara efektif sehingga media mampu membuktikan peranannya untuk melayani tugas-tugas pembangunan, baik pembangunan politik maupun pembangunan lainnya. Surat kabar menentukan apa yang dibicarakan oleh kebanyakan orang, apa yang dipikirkan sebagian besar orang, dan apa yang diharapkan orang dalam memecahkan masalah yang dihadapinya (Norton Long, dalam Rosadi, 1999). Media adalah pembentuk pengetahuan, opini, dan keyakinan yang berpengaruh dan tidak dapat dihindari dalam masyarakat modern (Nimmo, 1993).

Informasi dari berbagai media massa baik dari surat kabar, televisi, radio ataupun internet akan memengaruhi persepsi seseorang terhadap stimulus tertentu. Demikian juga informasi tersebut dapat berasal dari media interpersonal, tetangga ataupun teman sekantor. Menurut Nimmo ada dua saluran utama komunikasi interpersonal yang membantu belajar politik, yaitu keluarga dan lingkungan yang terdiri atas kawankawan dekat dan akrab yang dikenal sebagai sebaya (Nimmo,1993). Menurut Nimmo (1993) bahwa orang tidak dilahirkan dengan kepercayaan, nilai, dan pengharapan politik. Namun mereka menyusunnya secara sinambung jika dihadapkan pada rangsangan politik. Salah satu tingkat dalam tahap penyusunan personal ini terdiri atas segala sesuatu yang dapat dipelajari orang melalui komunikasi politik. Belajar politik berlangsung selama hidup manusia normal melalui proses yang disebut sosialisasi politik. Dalam konteks komunikasi politik inilah peranan sosialisasi menjadi penting dalam rangka menanamkan kepercayaan kepada publik pemilih.

Selain itu media massa memiliki kekuatan pengaruh yang besar dalam ikut mengendalikan arah perubahan mayarakat, khususnya dalam kerangka politik. Apa yang dilakukan media adalah sesuatu yang menjadi perilaku politik masyarakat, baik perilaku mendukung atau menentang (Muhtadi, 2008). Dalam perspektif sosiologis, menurut
Newcomb (dalam Muhtadi, 2008) perubahan sikap suatu masyarakat pada umumnya dipengaruhi oleh adanya informasi baru yang dipandang relevan dengan tuntutan kondisional. Besar kecilnya perubahan, salah satunya, bergantung pada kekuatan efek media yang menjadi salurannnya. Sebagai penyalur informasi, media massa merupakan kekuatan yang mampu memengaruhi sekaligus mengubah perilaku masyarakat, termasuk perilaku politik yang biasanya menjadi target dari partai-partai politik atau kekuatan-kekuatan politik lainnnya.

Informasi tentang pemilu legislatif yang berasal dari berbagai sumber akan memengaruhi persepsi seseorang terhadap pelaksanaan pemilu legislatif 2009. Sedangkan persepsi adalah pengalaman tentang objek, peristiwa, atau hubunganhubungan yang diperoleh dengan menyimpulkan informasi dan penafsiran pesan. Persepsi ditentukan oleh faktor personal dan faktor situasional (Desiderato dalam Jalaluddin Rakhmat, 1998) yang kemudian oleh Krech dan Richard S. Crutchfield (1977) menyebutkan faktor fungsional dan faktor struktural. Faktor fungsional berasal dari kebutuhan, pengalaman massa lalu dan hal-hal lain yang termasuk apa yang kita sebut faktor personal (Rakhmat, 1998). Perspektif kategori sosial berasumsi bahwa dalam masyarakat terdapat kelompok-kelompok sosial, yang reaksinya pada stimuli tertentu cenderung sama. Persepsi seseorang mengacu pada proses yang membuatnya menjadi tahu dan berpikir, menilai sifat-sifat kualitas dan keadaan internal seseorang (Taguliri dan Little John, 1978).

\section{METODE PENELITIAN}

Penelitian ini bersifat eksploratif dengan menggunakan pendekatan deskriptif kuantitatif. Dengan mengambil 3 (tiga) Kota daerah penelitian yaitu Kota Probolinggo, Kota Surabaya, dan Kota Blitar. Pengambilan tiga (3) lokasi penelitian tersebut dengan pertimbangan bahwa Kota Surabaya mewakili budaya arek sekaligus kota metropolitan yang 
terletak bagian wilayah utara, Kota Probolinggo mewakili budaya pendalungan sekaligus mewakili wilayah bagian timur yang dipandang lebih condong Islam tradisional, Kota Blitar mewakili budaya mataraman sekaligus wilayah barat dianggap nasionalis.

Populasi dalam penelitian ini adalah mereka yang sudah memiliki hak-hak politik dalam pemilu legislatif 2009. Pengumpulan data menggunakan teknik wawancara dengan instrumen daftar pertanyaan (kuesioner) tertutup dan terbuka kepada masyarakat yang mempunyai hak politik pada pemilu legislatif 2009. Pengumpulan data berupa data sekunder dilakukan dengan studi dokumentasi. Data primer dengan menggunakan instrumen daftar pertanyaan semi terstruktur baik terbuka maupun tertutup dengan mewancarai pemilih pada pemilu legislatif 2009. Jumlah sampel seluruhnya untuk tiga daerah penelitian Kota Probolinggo, Kota Blitar, dan Kota Surabaya sebanyak 900 orang dengan penyebaran distribusi dari masing-masing daerah penelitian diambil 300 responden. Adapun sasaran pendistribusian kuesioner dalam penelitian ini adalah mereka yang mempunyai hak pilih yang terpilih dengan pengambilan sampel menggunakan sistem acak.

\section{HASIL PENELITIAN DAN PEMBAHASAN}

\section{Peran Lembaga Sosialisasi}

Lembaga sosialisasi seperti televisi, surat kabar, KPU, partai politik, media internet maupun lembaga-lembaga lainnya dipandang oleh banyak pihak terutama para pemilih pemilu 2009 masih kurang berjalan dengan baik (52,0\%). Artinya mereka belum menjalankan fungsinya dengan semaksimal mungkin yang terutama belum membawa nuansa ke persoalan pendidikan politik. Walaupun demikian ada pula yang memandang bahwa media informasi sebagai lembaga sosialisasi dianggap sudah berjalan dengan baik $(39,8 \%)$.

Sejalan dengan itu bahwa media informasi sebagai lembaga sosialisasi dianggap sudah mendidik masyarakat pemilih dengan baik $(49,1 \%)$. Artinya lembaga tersebut dianggap sudah mengajak masyarakat untuk berdemokrasi dengan baik dan memberi pengertian kepada masyarakat akan pentingnya pemilu terhadap masa depan bangsa Indonesia. Namun ada sebagian masyarakat yang menganggap lembaga tersebut masih kurang dalam mendidik masyarakat $(43,3 \%)$ untuk berdemokrasi. Ada sebagian kecil masyarakat menganggap lembaga sosialisasi dalam pemilihan umum legislatif $2009 \quad(3,5 \%)$ tidak mendidik masyarakat, bahkan mereka ada yang tidak tahu menahu soal peran lembaga sosialisasi tersebut $(4,1 \%)$. Di sisi lain mereka kebanyakan berpendapat bahwa masyarakat sudah cukup untuk mendapatkan sosialisasi pada pelaksanaan pemilihan umum legislatif 2009 (63,8\%), namun ada sebagian kecil saja masyarakat yang memandang belum cukup mendapatkan sosialisasi $(34,5 \%)$. Bahkan ada sebagian kecil yang berpandangan bahwa masyarakat kurang mendapatkan sosialisasi $(1,8 \%)$.

Tidak semua responden memandang lembaga atau institusi sudah melakukan sosialisasi untuk memilih kandidat atau partai politik peserta pemilu. Hal ini dapat dibuktikan bahwa sebanyak $65,0 \%$ menyatakan mereka memilih bukan karena pengaruh sosialisasi, namun lebih banyak karena kedekatan atau melihat visi dan misi kandidat serta ingin menyalurkan aspirasi saja.

\section{Media Pengenalan Kandidat}

Program kampanye pemilu sangat penting untuk diketahui oleh masyarakat, apalagi kandidat/calon anggota legislatif. Di era pemilihan langsung peran media pengenalan baik itu media cetak, elektronik, maupun media-media lainnya menjadi sangat penting artinya. Oleh karena itu para kandidat sangat berkepentingan dengan media pengenalan apakah media cetak, elektronik maupun media lainnya.

Dari sekian banyak media ternyata masyarakat perkotaan terutama pemilih pemilu legislatif 2009 mengenal atau tahu 


\begin{tabular}{clc}
\multicolumn{3}{c}{ Tabel 1 } \\
Peran Lembaga Sosialisasi \\
\hline No & \multicolumn{1}{c}{ Peran Lembaga Sosialisasi } & F \\
\hline 1 & Sudah berjalan dengan baik & 39,8 \\
2 & Kurang berjalan & 52,0 \\
3 & Tidak berjalan & 4,1 \\
4 & Tidak tahu & 4,1 \\
\hline & Total & 100,0 \\
\hline
\end{tabular}

Sumber: data primer diolah

kandidat DPR RI dari iklan televisi $(79,5 \%)$ dan selain dari televisi mereka juga mengenalnya lewat selebaran/papan baliho, umbul-umbul (53,8\%). Kondisi hasil penelitian ini mendukung apa yang dinyatakan oleh Dan Nimmo (1993) bahwa media membentuk pengetahuan, opini, dan keyakinan yang berpengaruh dan tidak dapat dihindari dalam masyarakat modern.

Mereka mengenal kandidat anggota DPRD Provinsi lebih banyak lewat selebaran/papan baliho, umbul-umbul $(62,0 \%)$. Selain mereka mengenal lewat selebaran juga lewat iklan televisi $(48,5 \%)$ terutama televisi lokal. Namun untuk kandidat anggota DPRD mereka mengenal program-programnya lebih cenderung lewat selebaran/papan baliho dan umbul-umbul. Kondisi ini memperlihatkan bahwa media televisi ataupun iklan televisi lebih efektif dipakai untuk dijadikan kampanye oleh DPR RI. Televisi selain daya jangkaunya lebih luas, juga dipakai sebagai hiburan oleh masyarakat. Barangkali kemudahan masyarakat untuk mengakses media televisi, karena media tersebut lebih mudah untuk mengemas iklan-iklan politik para kandidat. Oleh karena itulah kandidat lebih banyak menggunakan media televisi untuk dijadikan media kampanye. Demikian juga dengan kandidat DPRD Provinsi selain menggunakan iklan politik berupa selebaran/papan baliho dan umbul-umbul dalam mengenalkan dirinya, tampaknya juga lebih suka dengan media televisi lokal untuk dijadikan media kampanye politiknya.

Selain media televisi, selebaran/papan baliho, dan umbul-umbul cukup efektif digunakan untuk kampanye para kandidat anggota DPR, DPRD Provinsi, dan DPRD Kota. Hal ini terbukti dari hasil penelitian pemilih pemilu legislatif 2009 mereka mengenal kandidat DPR RI sebanyak 53,8\%, demikian juga mereka tahu kandidat DPRD Provinsi lewat media selebaran/papan baliho dan umbul-umbul sebanyak 62,0\%. Bahkan untuk DPRD Kota mereka mengenal kandidat tersebut kebanyakan lewat media selebaran/papan baliho dan umbul-umbul sebanyak $81,3 \%$.

Dari sekian banyak media massa, surat kabar atau koran lokal maupun nasional masih banyak diminati oleh pemilih politik pada saat pemilu 2009. Hasil penelitian menunjukkan bahwa pemilih pemilu legislatif 2009, mereka mengenal atau mengetahui kandidat anggota DPR RI sebanyak 21,6\%, DPRD Provinsi sebanyak 35,7\%, dan DPRD Kota sebanyak $32,7 \%$. Sedangkan media lainnya seperti kampanye rapat umum cenderung tidak diminati oleh pemilih perkotaan. Hal ini dapat dilihat pada hasil penelitian yang menunjukkan pengakuan mereka mengenal kandidat lewat kampanye rapat umum untuk DPR RI hanya sebanyak 4,1\%, DPRD Provinsi sebesar 5,3\%, dan DPRD perkotaan hanya $16,4 \%$. Media lainnya seperti teman, tetangga, organisasi keagamaan, dan organisasi partai politik tidak begitu efektif digunakan sebagai media pengenalan atau sebagai sarana marketing politik para kandidat anggota DPR baik pusat, provinsi maupun kota. Namun untuk perkumpulan warga tampaknya lebih efektif sebagai media pengenalan kandidat, hal ini ditunjukkan hasil penelitian bahwa 
Tabel 2

Penggunaan Media Pengenalan Kandidat

\begin{tabular}{|c|c|c|c|c|}
\hline \multirow{2}{*}{ No } & \multirow{2}{*}{ Penggunaan Media Pengenalan Kandidat } & \multicolumn{3}{|c|}{ Kandidat Anggota Legislatif $(\%)$} \\
\hline & & DPRRI & DPRD Provinsi & DPRD Kota \\
\hline 1 & Televisi (iklan) & 79,5 & 48,5 & 23,3 \\
\hline 2 & Radio & 7,0 & 17,5 & 38,0 \\
\hline 3 & Surat kabar (Koran) & 21,6 & 35,7 & 32,7 \\
\hline 4 & Televisi \& radio & 15,2 & 17,0 & 17,5 \\
\hline 5 & Elektronika \& cetak & 18,1 & 14,0 & 12,3 \\
\hline 6 & Selebaran/papan baliho, umbul-umbul & 53,8 & 62,0 & 81,3 \\
\hline 7 & Kampanye rapat umum & 4,1 & 5,3 & 16,4 \\
\hline 8 & Teman & 2,9 & 5,3 & 10,5 \\
\hline 9 & Tetangga & 4,1 & 4,7 & 9,4 \\
\hline 10 & Organisasi keagamaan & 9,4 & 10,5 & 16,4 \\
\hline 11 & Perkumpulan warga & 2,9 & 2,9 & 47,0 \\
\hline 12 & Organisasi partai politik & 9,9 & 7,0 & 10,5 \\
\hline
\end{tabular}

Sumber: data primer diolah (kuesioner pilihan ganda).

sebanyak 47,0\% mereka mengenal kandidat lewat perkumpulan warga.

\section{Terpaan Media Iklan Politik}

Iklan politik berupa kampanye agar benar-benar memengaruhi perilaku politik pemirsa televisi harus benar-benar dikemas secara menarik. Iklan politik yang ditayangkan oleh partai politik peserta pemilihan umum legsilatif 2009 tidak semuanya dapat diketahui atau dilihat oleh pemirsa televisi, khususnya mereka pemilih pemilu 2009. Realitasnya ada sebagian kecil diantara mereka (pemilih) yang tidak tahu atau tidak pernah melihat iklan politik tersebut. Mungkin saja mereka tidak mengetahui atau apatis soal iklan politik. Hal ini menandakan bahwa iklan politik tidak sepenuhnya efektif untuk memengaruhi perilaku politik terhadap semua orang.

Bagaimana tingkat terpaan media televisi terutama iklan politik dapat memengaruhi perilaku politik pemirsa. Walaupun mereka sering melihat iklan politik pada massa kampanye partai politik pada pemilihan umum legislatif 2009 bukan berarti secara langsung mereka akan tertarik terhadap iklan tersebut. Dari sepuluh partai politik besar pemenang pemilu legislatif ada beberapa partai politik yang sering dilhatnya. Mereka yang sering melihat iklan partai demokrat sebesar $77,2 \%$, dan mereka yang menyatakan kadang-kadang melihatnya hanya $21,7 \%$. Sedangkan mereka yang menyatakan tidak pernah melihat/tidak tahu hanya $1,1 \%$ saja. Kondisi ini menggambarkan bahwa para pemilih ataupun masyarakat banyak yang mengetahui keberadaan iklan politik partai demokrat di televisi. Tabel 3, memperlihatkan bahwa mereka yang menyatakan sering melihat iklan politik Partai Golkar sebanyak $72,5 \%$. Sedangkan mereka yang menyatakan kadang-kadang melihatnya hanya sebanyak $26,9 \%$ dan mereka yang tidak tahu menahu atau tidak pernah melihatnya hanya $0,6 \%$. Kondisi iklan politik PDIP sebagai pemenang pemilu legislatif 2009 hampir sama dengan Partai Demokrat maupun Partai Golkar. Mereka sebagian besar $(70,7 \%)$ menyatakan sering melihat iklan politik Partai Demokrasi Indonesia Perjuangan, sedangan sebagian kecil lainnya menyatakan hanya kadangkadang saja melihatnya.

Demikian juga dengan iklan politik Partai Gerindra. Partai Gerindra ternyata sering dilihat iklan politiknya oleh pemirsa ataupun pemilih pemilu legislatif 2009. Mereka yang menyatakan sering melihat iklan politik Partai Gerindra di televisi sebanyak 
Tabel 3

Iklan Politik Parpol Yang Dilihat

\begin{tabular}{lcccc}
\hline \multirow{2}{*}{ Partai Politik } & \multicolumn{3}{c}{ Iklan paling sering dilihat (\%) } & Jumlah \\
\cline { 2 - 4 } & Sering dilihat & Kadang-kadang & $\begin{array}{c}\text { Tidak pernah } \\
\text { Lihat/tidak tahu }\end{array}$ & \\
\hline Demokrat & 77,2 & 21,7 & 1,1 & 100 \\
Golkar & 72,5 & 26,9 & 0,6 & 100 \\
PDI-P & 70,7 & 28,7 & 0,6 & 100 \\
PKS & 45,6 & 51,5 & 2,9 & 100 \\
PAN & 39,7 & 51,5 & 8,7 & 100 \\
PKB & 32,2 & 55,6 & 12,2 & 100 \\
PPP & 32,1 & 62,0 & 5,9 & 100 \\
Hanura & 44,4 & 53,9 & 1,7 & 100 \\
Gerindra & 55,6 & 40,9 & 3,5 & 100 \\
\hline
\end{tabular}

Sumber: data primer diolah

$55,6 \%$.

Tampaknya sangat berbeda dengan PKS, PAN, PKB, PPP maupun Partai Hanura. Ada kecenderungan kebanyakan para pemilih pada pemilu 2009 jarang atau kadang-kadang melihat iklan politik dari kelima partai politikyaitu PKS, PAN, PKB, PPP, dan Partai Hanura. Hal ini dapat dilihat pada tabel bahwa mereka yang menyatakan kadangkadang melihat iklan politik PKS lebih banyak dibandingkan mereka yang sering meilihatnya. Demikian juga dengan keberadaan iklan politik Partai Amanat Nasional (PAN) yang ditayangkan televisi, mereka kebanyakan $(51,5 \%)$ menyatakan kadang-kadang melihat iklan politik partai tersebut. Sedangkan mereka yang sering melihatnya sebanyak $39,7 \%$, dan yang lainnya tidak tahu menahu. Hal yang sama terjadi pada iklan politik partai PKB, PPP, dan Partai Hanura, mereka ada kecenderungan hanya kadang-kadang melihat iklan partai politik. Kondisi ini dapat dilihat pada hasil penelitian, mereka yang menyatakan kadangkadang melihat iklan politik Partai Kebangkitan Bangsa sebanyak 55,6\%, sedangkan mereka yang menyatakan sering melihat iklan tersebut lebih sedikit yaitu sebanyak $32,2 \%$. Untuk iklan politik Partai Persatuan Pembangunan (PPP) juga ada kecenderungan jarang atau kadang-kadang dilihat oleh pemilih $(62,0 \%)$ dan mereka yang menyatakan sering melihatnya hanya sebanyak 32,1\%. Demikian juga dengan Partai Hanura ada kecenderungan jarang dilihat oleh pemilih pemilu legislatif 2009 $(53,9 \%)$, dan mereka yang sering melihat iklan politiknya sebanyak 44,4\%.

\section{Daya Tarik Iklan Politik}

Bagaimana dengan daya tarik iklan politik bagi pemilih? Penampilan iklan politik yang ditawarkan partai politik pada saat kampanye pemilu legislatif 2009 yang ditampilkan di stasiun televisi, surat kabar, maupun yang berbentuk baliho menurut para pemilih kebanyakan menarik baik iklan melalui televisi, maupun pembaca. Seperti iklan politik yang ditampilkan Partai Demokrat (PD) kebanyakan (84,3\%) dipandang menarik. Dipandang menarik bukan berarti secara otomatis langsung akan memengaruhi perilaku politik pemilih dalam menentukan pilihan politiknya, masih banyak faktor yang ikut memengaruhinya. Namun hal ini paling tidak dapat dijadikan rujukan atau pertimbangan bagi partai politik yang bersangkutan dalam menentukan sikap pada pemilihan umum mendatang.

Mereka kebanyakan memandang bahwa iklan politik Partai Demokrat menarik karena partai demokrat lebih realistis menggambarkan kondisi masyarakat yang ada. Walaupun partai demokrat merupakan 
Tabel 4

Ketertarikan Terhadap Penampilan Iklan Politik

\begin{tabular}{lcccc}
\hline \multirow{2}{*}{$\begin{array}{c}\text { Partai } \\
\text { Politik }\end{array}$} & \multicolumn{3}{c}{ Ketertarikan terhadap Iklan politik } & Jumlah \\
\cline { 2 - 4 } & Menarik & $\begin{array}{c}\text { Tidak } \\
\text { menarik }\end{array}$ & $\begin{array}{c}\text { Tidak } \\
\text { tahu }\end{array}$ & \\
\hline Demokrat & 84,3 & 2,9 & 12,8 & 100 \\
Golkar & 73,6 & 5,3 & 21,1 & 100 \\
PDI-P & 67,8 & 11,1 & 21,1 & 100 \\
PKS & 52,1 & 37,0 & 10,9 & 100 \\
PAN & 59,8 & 33,5 & 6,7 & 100 \\
PKB & 41,2 & 55,0 & 3,8 & 100 \\
PPP & 53,2 & 31,0 & 15,8 & 100 \\
Hanura & 25,8 & 59,1 & 15,1 & 100 \\
Gerindra & 64,4 & 29,4 & 6,2 & 100 \\
\hline
\end{tabular}

Sumber: data primer diolah

salah satu partai politik yang dipandang baru muncul di panggung politik namun parpol tersebut cukup berhasil dalam menggerakkan massa. Hal ini karena figur pimpinan partai politiknya yang cukup berwibawa.

Dari tabel 4, diketahui bahwa penampilan iklan politik Partai Golongan Karya, kebanyakan dipandang oleh pemilih menarik $(73,6 \%)$ dan mereka yang tidak memberi penilaian atau tidak berpendapat apapun hanya $21,1 \%$. Mereka beralasan bahwa menariknya iklan Partai Golkar lebih menunjukkan kearah Indonesia yang lebih baik dan berdasarkan pada realitas yang ada pada masyarakat masa kini. Partai lainnya yang iklan politiknya dipandang menarik antara lain PDIP, PKS, PAN, PPP, dan Gerindra. Kelima partai politik tersebut menarik karena memberikan harapan pada masyarakat. Mereka yang menyatakan menarik kebanyakan status pekerjaannya sebagai tukang becak, buruh pabrik, ibu-ibu rumah tangga, wiraswasta, dan sebagian berlatar belakang sebagai pegawai atau karyawan. Sedangkan iklan politik yang penampilannya dipandang tidak menarik adalah PKB, dan Partai Hanura.

Kemudian prioritas program kampanye yang menarik antara lain reformasi birokrasi, perbaikan pelayanan, di bidang pendidikan misalnya pendidikan murah/gratis, perbaikan mutu, peningkatan
SDM guru, di bidang hukum seperti kepastian hukum, pemberantasan KKN, ketertiban, peningkatan kesadaran hukum, di bidang pertanian/ekonomi seperti harga murah, stabilitas ekonomi, peningkatan produktivitas, kemiskinan, lapangan kerja, pengangguran, kesenjangan sosial. Dan bidang keamanan seperti stabilitas keamanan, serta kriminalitas.

\section{Persepsi: Pengaruh Media Komunikasi dan Orientasi Politik}

Pengaruh di sini diartikan sejauhmana peran media massa dalam memengaruhi pemilih untuk menentukan pilihan politiknya. Apakah mereka memilih berdasarkan pertimbangan karena sering muncul di media massa ataukah karena pertimbangan lainnya?. Dari hasil penelitian menunjukkan, media massa televisi berupa iklan politik berpengaruh dan dijadikan pertimbangan mereka dalam memilih (60,2\%). Mereka menganggap bahwa iklan politik yang ditawarkan oleh kandidat pada televisi dapat diseleksi misi, visi kandidat. Dengan demikian mereka akan lebih tahu tentang kualitas kandidat.

Demikian juga dengan para pemilih yang sering menggunakan media internet merasakan atau menganggap berpengaruh terhadap pilihan politiknya $(56,2 \%)$. Mengapa demikian berpengaruh terhadap pemilihan politiknya. Dengan kandidat yang sering 


\section{Tabel 5}

Pengaruh Media Informasi

\begin{tabular}{llccc}
\hline \multirow{2}{*}{ No. } & & \multicolumn{3}{c}{ Pengaruh Media Informasi (\%) } \\
\cline { 3 - 5 } & & Berpengaruh & $\begin{array}{c}\text { Kurang } \\
\text { berpengaruh }\end{array}$ & $\begin{array}{c}\text { Tidak } \\
\text { berpengaruh }\end{array}$ \\
\hline 1 & Televisi (iklan) & 60,2 & 31,4 & 8,4 \\
2 & Internet & 56,2 & 31,6 & 12,2 \\
3 & Radio & 23,6 & 47,8 & 28,6 \\
4 & Surat kabar & 51,3 & 44,7 & 4,0 \\
5 & Selebaran/ papan baliho, umbul-umbul & 33,2 & 44,5 & 22,30 \\
6 & Kampanye rapat umum & 2,9 & 32,6 & 64,5 \\
7 & Teman/ sahabat/tetangga & 29,7 & 45,2 & 25,1 \\
8 & Organisasi keagamaan & 45,9 & 32,3 & 21,8 \\
9 & Perkumpulan warga & 51,5 & 29,9 & 18,6 \\
\hline
\end{tabular}

Sumber: data primer diolah

tampil di media internet, para pemilih akan lebih mengetahui tentang visi, misi, asal partai, kualitas diri kandidat, dan yang lebih penting adalah para pemilih akan lebih mengetahui tentang apa yang kandidat lakukan untuk kepentingan masyarakat selama ini.

Kemudian radio dianggap kurang berpengaruh terhadap pertimbangan dalam menentukan pilihan politiknya $(47,8 \%)$, namun di sisi lain media surat kabar justru tampaknya efektif untuk memengaruhi pilihan politiknya $(51,3 \%)$. Mengapa radio kurang dijadikan rujukan atau kurang dipertimbangkan dalam menentukan pilihan politiknya? Para pengguna media radio menganggap bahwa radio sangat terbatas untuk mengaksesnya, terbatas pada pendengaran dan hanya mendengar suaranya saja, namun tidak bisa mengakses lebih jauh seperti bagaimana penampilan atau performennya. Para pembaca surat kabar ternyata lebih tertarik pada kandidat lewat surat kabar, dengan demikian mereka akan lebih banyak memengaruhi perilaku politiknya dan mereka akan lebih mempertimbangkan untuk dijadikan referensi politiknya. Mengapa para pembaca surat kabar kebanyakan mempertimbangkan pilihan politiknya?. Mereka beranggapan bahwa dengan sering tampilnya di media surat kabar mereka akan lebih tahu tentang visi, misinya untuk kepentingan bangsanya bahkan mereka akan lebih tahu tentang kualitas pribadinya seperti kejujuran, popularitas, dan integritas dirinya. Tentunya surat kabar ini bukan satusatunya yang menjadikan faktor pengaruh terhadap pilihan politiknya.

Hasil penelitian ini mendukung teori yang menyatakan bahwa pers tidak mungkin banyak berhasil memengaruhi apa yang dipikirkan orang, tapi lebih berhasil untuk membentuk persepsi orang tentang apa yang dianggapnya penting (Rosadi,1999) Media adalah pembentuk pengetahuan, opini, dan keyakinan yang berpengaruh dan tidak dapat dihindari dalam masyarakat modern. Informasi dari berbagai media massa baik dari surat kabar, televisi, radio ataupun internet akan memengaruhi persepsi seseorang terhadap stimulus tertentu (Nimmo, 1993).

Ternyata selebaran/papan baliho, umbul-umbul kurang dijadikan pertimbangan dalam menentukan pilihan politiknya $(44,5 \%)$. Demikian pula bahwa kampanye dalam bentuk rapat umum tidak dijadikan referensi dalam menentukan pilihan politiknya pada kandidat tertentu $(64,5 \%)$. Kondisi seperti ini menunjukkan bahwa kampanye yang berbentuk rapat umum tidak diminati oleh pemilih. Tidak itu saja 
informasi dari teman/sahabat maupun tetangganya tentang kandidat ataupun partai politik tertentu masih kurang berpengaruh terhadap pilihan politiknya $(45,2 \%)$. Walaupun demikian mereka ada yang menyatakan bahwa nasihat ataupun informasi dari teman/sahabat maupun tetangganya masih dipertimbangkan $(29,7 \%)$.

Mereka kebanyakan mempersepsikan bahwa media komunikasi lewat media organisasi keagamaan maupun media perkumpulan warga efektif untuk memengaruhi pemilih. Hal ini terbukti bahwa para pemilih yang sering ikut perkumpulan warga maupun organisasi keagamaan seperti pengajian ataupun bentuk lainnya menyatakan bahwa kandidat yang sering berkomunikasi lewat organisasi keagamaan ataupun memanfaatkan perkumpulan warga akan dijadikan pertimbangan ataupun berpengaruh terhadap pilihan politiknya. Mereka beralasan bahwa dengan kedekatan kandidat pada pemilih dalam bentuk kehadiran mereka pada setiap kesempatan akan menunjukkan kepedulian kandidat pada pemilih. Dengan demikian mereka akan lebih tahu tentang visi, misi, integritas, performen, dan kualitas dirinya. Media komunikasi baik itu media cetak, media elektronik, kampanye rapat umum, organisasi keagamaan, maupun perkumpulan warga mempunyai pengaruh sendiri-sendiri terhadap setiap pemilih. Lalu yang menjadi pertanyaan berikutnya adalah bagaimana pilihan politik mereka, apakah berorientasi pada pilihan ideologi atau problem solving policy?

Dari hasil penelitian ternyata bagi mereka yang berpendidikan menengah ke bawah kebanyakan memilih kandidat ataupun partai politik cenderung karena orientasi ideologi partai $(61,4 \%)$, walaupun demikian masih ada diantara mereka yang berpendidikan menengah bawah orientasi pilihan politiknya pada problem solving policy $(38,6 \%)$ seperti soal program penanganan pengangguran atau kesempatan kerja, kemiskinan, persoalan pendidikan, dan sebagainya.

Tampaknya agak berbeda dengan mereka yang berpendidikan tinggi orientasi pilihan politiknya relatif banyak pada problem solving policy $(52,5 \%)$, ada pula mereka yang orientasi politik pada ideologi $(21,2 \%)$. Ada pula mereka yang orientasi politiknya campuran antara ideologi maupun problem solving policy $(26,3 \%)$. Orientasi politik campuran ini selain mempertimbangkan ideologi yang diyakininya juga mempertimbangkan persoalan-persoalan kebijakan yang merupakan solusi untuk menjawab permasalahan seperti program kerja terhadap persoalan lapangan pekerjaaan, pertanian, keamanan, persoalan kemiskinan yang semakin membengkak jumlahnya, pendidikan, dan lain sebagainya.

\section{PENUTUP}

\section{Simpulan}

Media sosialisasi pada saat pemilu 2009 masih kurang berperan dengan baik dan kurang mendidik masyarakat untuk berdemokrasi. Mereka mengenal kandidat DPR RI lebih banyak melalui iklan televisi , selebaran/papan baliho, umbul-umbul. Demikian juga pemilih mengenal kandidat DPRD Provinsi mempunyai kecenderungan yang sama dengan DPR RI yaitu melalui iklan televisi lokal, selebaran/papan baliho, umbul-umbul. Sedangkan mereka mengenal atau mengetahui kandidat DPRD Kota lebih banyak melalui selebaran/papan baliho, umbul-umbul, dan perkumpulan warga.

Daya tarik iklan politik politik sangat variatif artinya hampir semua partai politik peserta pemilu legislatif 2009, iklan yang mereka tawarkan relatif menarik seperti. Mereka yang tertarik pada iklan politik beranggapan bahwa realistis. Iklan politik Partai Golkar menggambarkan Indonesia ke arah yang lebih baik dan realistis. Sedangkan iklan politik yang menarik dari PDI-P, PKS, PAN, PPP, dan Partai Gerindra adalah memberi harapan pada masyarakat Indonesia.

Kemudian prioritas program kampanye yang menarik antara lain reformasi birokrasi, perbaikan pelayanan, pendidikan murah/gratis, di bidang hukum seperti kepastian hukum, pemberantasan 
KKN, ketertiban, pertanian, stabilitas ekonomi, peningkatan produktivitas, kemiskinan, lapangan kerja, kesenjangan sosial, dan bidang keamanan seperti stabilitas keamanan, serta kriminalitas.

Pemilih mempersepsikan bahwa media komunikasi berupa iklan politik lewat televisi, internet, surat kabar efektif untuk memengaruhi dan dijadikan pertimbangan dalam memilih kandidat. Demikian juga media komunikasi lewat organisasi keagamaan dan perkumpulan warga dipandang oleh pemilih lebih efektif untuk memengaruhi dan dijadikan pertimbangan pemilih. Sedangkan media komunikasi seperti radio, selebaran, papan baliho, umbulumbul, teman/sahabat, ataupun tetangga dipandang kurang efektif untuk memengaruhi pemilih. Media komunikasi yang dipandang tidak efektif untuk memengaruhi pemilih adalah kampanye berupa rapat umum.

Orientasi politik bagi mereka yang berpendidikan menengah-bawah cenderung pada pilihan ideologi, sedangkan mereka yang berpendidikan tinggi lebih cenderung orientasi politiknya pada problem solving policy ketimbang persoalan ideologi.

\section{DAFTAR PUSTAKA}

Depari, Eduard dan Mac Colin, Andrews (Ed).(1995).Peranan Komunikasi Massa dalam Pembangunan. Yogyakarta: Gajah Mada University Press.

Klapper, J. (1960). The Affect of Mass Communication. New York: Free Press.

Liliweri, Alo. (1991). Memahami Peran Komunikasi Massa dalam Masyarakat. Bandung: Citra Aditya Bakti.

Mc. Quail, Denis and Steven Weindahl. (1995). Model-Model Komunikasi. Jakarta: Institut Ilmu Sosial dan Ilmu Politik.

Mubarok, M. Mufti. (2005). Suksesi Pilkada. Surabaya: Java Pustaka.
Mc Quail, Dennis. (1996). Teori Komunikasi Massa. Jakarta: Erlangga.

Nimmo, Dan. (1989). Komunikasi Politik, Khalayak dan Efek. Bandung: Rosdakarya.

............... (1993). Komunikasi Politk, Komunikator, Pesan, dan Media. Bandung: Rosdakarya

Muhtadi, Asep Saeful. (2008). Komunikasi Politik di Indonesia:Dinamika Islam Politik Pasca Orde Baru. Bandung: Remaja Rosdakarya.

Prihatmoko, Joko J, Pemilihan Kepala Daerah Langsung: Filsafat, Sistem dan Problema Penerapan di Indonesia. Yogyakarta: Pustaka Pelajar.

Rakhmat, Jalahuddin. (1998). Psikolgi Komunikasi. Bandung: Remaja Rosdakarya.

Rosadi, Udi. (1999). "Teori dan Model Penelitian Efek Agenda Setting Media Masa". Jakarta: makalah Pendidikan dan Latihan Penelitian Deppen RI.

Sanit, Arbi. (2005). Sistim Politik Indonesia: Kestabilan, Peta, Kekuatan Politik dan Pembangunan. Jakarta: Raja Grafindo Persada.

Surbakti, Ramlan. (1992). Memahami Ilmu Politik. Jakarta: Gramedia Widiasarana. 